\title{
USING OF READING, ENCODING, ANNOTATING, AND PONDERING (REAP) TECHNIQUE TO IMPROVE STUDENTS' READING COMPREHENSION (A Classroom Action Research at Eighth Grade Students in MTSN 1 Kota Bengkulu in Academic years 2016)
}

\author{
Fera Zasrianita \\ Dosen Program Studi Tadris Bahasa Inggris IAIN Bengkulu \\ Korespondensi: Jalan Raden Patah, Kelurahan Pagar Dewa, Selebar, Kota Bengkulu, Bengkulu 65144 \\ e-mail: ferazasrianita@ymail.com
}

\begin{abstract}
The researcher found the problem at MTSN 1 in the city of Bengkulu at grade VIII I that students got difficulty in comprehending reading texts, and in understanding meanings of words in paragraphs, and teachers techniques made the students bored. Therefore, the purpose of the research is to improve students' reading comprehension through REAP techniques. The subject of the research is the students of grade VIII I consisting of 27 students, 14 female students and 13 male students. The instruments of the research are reading tets, observation sheetteacher and the students, interview guide and that for documentary study. The results of the research show that the REAP teachniques are effective in improving the students' reading comprehension. The students got involved directly and were able to cooperate with their peers during the teaching-learning process. The research was conducted in two cycles an the test was administered at the end of each cycle. From the average mean scores, it could be seen that there was improvement of the the students' reading ability. In cycle I, the mean score was 70.5 and in cycle 2, it was 78.7, and at the Post assessment, it was 82.2. It means that the students' mean scores has reached the research target. Thus, it can be concluded that REAPtechniques can improve the students' readng comprehension.
\end{abstract}

Kata Kunci: REAP (Reading, Encoding, Annotating, and Pondering) technique, Students' reading comprehension

\section{BACKGROUND OF THE PROBLEM}

$\mathrm{R}$ eading is one of the most important skills. It is also a major pillar upon which teaching and learning process. Reading is one of the factors influences students to be success in learning and teaching. It is because the most materials of teaching and learning are in written form. For the successful reading process, an individual must process basic intellectual ability or background knowledge and experience relating the topic of reading, reading is usually conceived of as a solitary activity in which the reader interacts with the text in isolation (David, 1995: 72). It means that students need to improve their reading skill in order to understand the teaching and learning materials. 
Reading is a common place of teacher education that teachers tend to teach by the method which used by the teachers who taught them, It means reading is important skill, when readers read, they are also learned and have purpose to get knowledge, they used their thinking, skill or strategies to conclude what the meaning. Another definition of reading comprehension strategy is as a cognitive or behavioral action that is enacted under particular contextual (Napitupulu, 2012: 2).

Reading comprehension is a complex process that demands much from the reader it is a result of the reader interacting with the text. Good comprehension is a critical step in the development of reading skills. It means that teaching students to read with a good comprehension must be teachers' priority, reading is the process of constructing meaning through the dynamic interaction among: (1) the reader's existing knowledge; (2) the information suggested by the text being read; and (3) the context of the reading situation (Fauziyah, 2014: 5).

In reading skill, students find difficulties to comprehend the text books. The difficulty is caused by some factors, such as incomprehensible text, difficulties words, vocabulary, length of the text, and any other. In order to make the students interested in studying English, the teacher has to have various techniques in teaching English. One of the technique in teaching reading is by using REAP Technique. REAP is an acronym for Reading, Encoding, Annotating, Pondering. In addition, they also say that this technique starts from the premise that best readers when asked to communicate the ideas gleaned from a passage they have read (Marantika, 2013: 72).

Based on observation was done by researcher on February, $4^{\text {th }} 2016$ toward students at MTSN 1 Kota Bengkulu in VIII 1 class, the result showed that students have variation in comprehending English text, but the most students have score under average was 55.18, it caused they get difficulties in understanding a text, comprehending the meaning of words in the text, the students cannot get message from the text. Moreover, the researcher also found some English teachers seldom apply various techniques in teaching and learning reading in the classroom.

Based on explanation above, the problem of this research is formulated as the following Question. "Can the REAP technique improve students' reading comprehension?".

\section{METHOD}

Design of this research used a classroom action research (CAR). This research was done by researcher at grade VIII 1 of MTSN I Kota Bengkulu. This Class consisted of 27 students. Fourteen (14) females and thirteen (13) males students. The reason why researcher choose that class because base on observation was done on February $4^{\text {th }}$ 2015 in this class have variation of their score in reading comprehension from highest scores above average and a lot of their score under average is a minimum completeness criteria (KKM) is 75 . The problem faced by students were difficult to understands and get information that they needed in reading text. This research was done in location at MTSN 1 Kota Bengkulu. This school has some facilities that helped the teaching and learning process, such as; library, language lab, etc. The procedures of this 
research were as follow; pre-assessment, cycle 1 , cycle 2 and post assessment. The instrument was done used in this research is a reading test. Reading is essential for successfully completing all college-level courses (Marantika, 2013). In other words, college students who are more proficient readers are most likely to experience more success in their courses". It will be prepared by the researcher to measure level and improvement of the students in reading comprehension. And observation of teacher, students' checklist and field notes. Data analyzing is the last step in research, in the step researcher will interpretation of data that has resulted in the subject (Martono, 2012: 145). There are two stages of data analysis technique, such as:

a. The individual score of the students' reading comprehension test by researcher was done following formula:

$$
\begin{aligned}
& \mathrm{P}=\frac{X}{X i} 100 \\
& \text { The explanation: } \\
& \mathrm{X}: \text { The total of the students' } \\
& \text { correct items } \\
& \text { Xi: The total of items } \\
& \mathrm{P} \text { : percentage (Sujana, 2010: 94) }
\end{aligned}
$$

Table of Students' score Interval INTERVAL QUALITATIVE

\begin{tabular}{cc}
\hline 86-100 & Very Good \\
\hline $\mathbf{7 1 - 8 5}$ & Good \\
\hline $\mathbf{5 6 - 7 0}$ & Fair \\
\hline$\leq 55$ & Poor \\
\hline
\end{tabular}

\section{DISCUSSION}

Reading comprehension is a communication that making connection is relating what has been read to personal experience to get information. Comprehension that means an ability to understand the meaning of something or knowledge acquires as a result. In supporting to this statement, reading comprehension is the capability of understanding what the reader read (Penny, 1996: 7). In this understanding the reader should recognize eight skill, they are recognizing definition and example, enumerations, heading and sub headings. Signal words, main ideas in paragraph and short selections, knowing how to outline, how to summarize, and understanding graph and table. Comprehension is achieved gradually, as you move from a general feeling about what something means to a deeper level of understanding.

Reader has to be able to take messages from text in order to comprehend, reading is seen as a selective process taking place between the reader and the text, in which background knowledge and various types of language knowledge interact with information in the text to contribute context comprehension (Weir, 1993: 64). So, concluded reading can be defined as a process of looking at and understanding what is written but as not simple as that. If we wanted to understand a text as fully as possible, we would need to understand every sentence in these four ways (Nuttal, 1996: 37). Furthermore, reading as the meaningful interpretation of printed or written verbal symbols. It means that reading does the writer intend a result of interaction between the perception graphic symbols that represent language skills, cognitive skill and knowledge.

Reading is an activity to get information, Reading a process constructing meaning through the dynamic interaction among: 1.The reader's existing knowledge, 2.The 
information suggested by the text being read, and 3.The context of the reading situation (Nuttal, 1996: 37). Reading is one of the important skills which have to be learned by the students in order to master English well. Reading is also included into receptive skill besides listening. Receptive skill is the way in which people extract meaning from the discourse they see or hear.

\section{Teaching and Reading Activities}

Reading activity is not merely reading the text, but reading comprehends the text. Some students may think like that. To give clear boundaries of reading there were some assumptions about the nature of reading. He said that

1. Students need to perceive and decode letters I order to read words.

2. Students need to understand all the words in order to understand all the words in order to understand the meaning of a text.

3. The more symbols (letters or words) there are in the text, the longer it will take to read it.

4. We gather meaning from what we read

5. Students' understand of a text come from understanding the words of which it is composed (Penny, 1996: 138).

Furthermore, there some principle of teaching reading, there are eight principles of teaching reading, (1) exploit the readers background knowledge, (2) build a strong vocabulary base, (3) teach for comprehension, (4) work on increasing reading rate, (5) teach reading strategies, (6) encourage students to transform strategies into skills, (7) build assessment and evaluation into your teaching and (8) strive for continuous improvement as a reading teacher (Nunan, 1989: 89).
Those principles will help the teacher to teach reading in order to help students reach the main goal of reading. That is comprehension. In teaching reading, the teacher should conduct the activity in good process and sequences; there were some tips on good reading, 1. Pay attention to titles, subheadings, and it the case of books, tables of contents, 2 . Look for the main idea, 3. Determine the type of essay you are reading, 4. Develop your vocabulary, ((Nunan, 1989: 89) Continue, the text is a story; learners suggest what might happen next.

1. Preface, the text is a story; learner suggestion what might have happen before.

Gapped text, towards the end of the text, four or five gaps are left another definition of reading activities, Ideas for reading activities:

2. Pre-question, a general question is given before reading, asking the learners to find out a piece of information central to the understanding of the text.

3. Do-it-yourself questions, learners compose and answer their own questions.

4. Provide a title, learners suggest a title if none was given originally.

5. Summarize, learners summarize the content in a sentence or two.

6. That can only be filled in if the text has been understood.

7. Mistake in the text, the text has, towards the end, occasional mistakes (wrong words; or omission).

8. Comparison, there are two texts on a similar topic, learners note point of similarity or different of content.

9. Responding, the text is a letter or a provocation article, learners discuss how they would respond or written an answer.

10. Re-presentation of content. (Penny, 1997: 146). 


\section{Reading Encoding Annotating and Pondering (REAP) Technique.}

REAP is a technique for helping reader read and understanding a text, REAP is an acronym for Reading, Encoding, Annotating and Pondering, there are four steeps of reading in REAP: a). R: Read on your own words, b). E: Encode the text by putting the gist of what you read in your own words. C). A: Annotate the text by writing down the main ideas and the author's. d). P: Ponder what you read by thinking and talking with others in order to make personal connections, develop questions about the topic, and/or connect this reading to other reading you have done message (Allen, 2012). REAP is an acronym for Reading, Encoding, Annotating, Pondering. In addition, they also say that this technique starts from the premise that readers best when asked to communicate the ideas gleaned from a passage they have read The REAP technique consist of:

$\mathrm{R}$ : Read to gather the author's ideas;

E: Encode the author's ideas into one owns' Language.

A: Annotate those ideas in writing for one or for sharing with others;

P: Ponder the significance of the annotation, (Marantika, 2013: 72). Another definition, of REAP technique aims to help the students as readers to become more effective readers and to think critically about the material that they have read (John, 2000: 46).

Some more explanation about REAP technique as follow:

1. Reading is the first step in REAP technique. In this step, the reader read the whole text. The purpose of this activity is to catch the main idea or the main content of the text. In reading step, the reader can read the text about one or two times, the others may be three time. It is catching the idea from the text.
2. The second step are encoding, in this step reader explore the idea into their words. In encode step it is demanded the critical thinking of the reader to concept the idea of the text into their own understanding. Every reader may be has different way and different language to understand the text.

3. The third step is Annotating, this is the key process of REAP technique. In this step the readers write down what they have got in Reading and Encode step before.

4. The last step in the technique is Pondering, this step is done by reviewing by the reader itself, then sharing and discussing with the others. (Dawit, 2014: 83-84).

The steps in REAP technique includes into four steps:

The first steps in REAP technique is Read step. In this step, the students will be asked to read a text selection by the teacher. After that, in Encoding step, the students try to encode by putting the gist of what they read in their own words. Then, the students follow Annotate step. In this step, the students will be asked to annotate the text by writing down the main ideas (notes, important words, and quotes) and writers' message. Finally, the students do Pondering step. In this step, the students ponder what they have read by thinking and talking with others in order to make a personal connection, develop the questions and connect their reading with others reading. Those all steps are designed to guide the students to comprehend a text and interpret the text clearly by their own words. (Janet. 2004).

Reap technique is also assist in combining several skill to facilities discussion about reading material, Generally REAP is based on premises: a) A text becomes more meaningful when readers communicate its information to themselves or others. b) 
Students read with added attention when they are to write about it afterward, so the once passive reading becomes more actives. c) Students tend to process information more deeply and more meaning when they write about it afterward. There were some advantages of REAP technique, explained that REAP technique develop in a student greater of the author's role in writing and to improve reading comprehension. (Susanti Rini, 2012: 4). This strategy help students build between the text and their own words to enable them to communicate their understanding of the text.

Based on the steps in REAP, the REAP technique has some advantages to help students comprehending a text. Firstly, the students can revisit the text several times as they work through the REAP process. Secondly, students can understand the text by restate main ideas and important points of the text in their own words. Thirdly, the students also can make a personal connection between the texts with their understanding. And the last, annotating steps can improve the students ${ }^{\text {ee }}$ attention and make reading a more active process. (Susanti Rini, 2012: 16) So, REAP is a technique to guide students to comprehend a text by connecting between a text with their own words. REAP is an acronym for four steps. First, students read a text independently. Secondly, students encode the text by writing the ideas in their own words. Thirdly, they annotate a text using quotes, phrases or words. Fourthly, they ponder the text by engaging in group discussion or peers.

\section{Implementation of REAP Technique toward Reading Comprehension}

The first activity that researcher will be held is the teacher helps the student in building their background knowledge about the will be learned. Such as shows some pictures, the title of the text and asks some questions. After that, the students may have some references in their mind about text that they will read.

The next step is dividing the students into some groups. In each group consist of three or four people. Because there are four steps in REAP technique divided students make a group can help them in learning reading with REAP. Then the first activity should teacher do is giving a narrative text to each member of the group.

Next, the teachers guide students to do the first phase of REAP technique; Reading, in this phase, the teachers can ask one of the students to read aloud in front of the class, during this students read aloud, the other students listening carefully. After that the teachers ask all of students to read the text by two or three times by themselves. This activity may take time about 10 until 15 minutes.

The second activity is Encoding; in this phase the teacher leads the students to explore their idea about that text into their own words, also some of the difficult vocabularies. In this stage, the students may discuss to other member of their own group. In Encode step the teacher also add an activity; discussing the new or difficult vocabulary. Teacher asks a student of each member to write down the difficult vocabularies in the whiteboard. After that, the teacher leads the discussion about the meaning or the synonym of the difficult vocabularies.

The third step is Annotating, this activity take time about 15 minutes. in annotating step, the student should write down their idea about the content of the

Narrative text that teacher gave them before. To make it easier, the students can make the generic structure of the narrative text they have read, such as identification, description and conclusion of the story line and the contents of it. In this activity, the student work alone. The teacher looked around 
the classroom for checking the students work. In this activity there is possibility that there are some groups or students who are not understand about what to do in Annotating step. The last stage of REAP technique is Pondering, in this stage, the students work by group. They pondering the significance of text, by thinking, discussing, or talking with their member of the group, then make one perfect summarize about the text. The summary is using theirs' own language.

\section{Result}

The object of the research was consisted of twenty seven students of MTSN 01 Kota Bengkulu in VIII.1 class that it were fourteen females and thirteen males, they were lack in comprehending English reading text, difficult to got main idea in a text and also their motivation on reading were very low.
Through this study, the researcher tried improve the students' comprehension on reading by apply REAP technique.

The result of student's comprehension on reading was analyzed and comparison through percentage from each steps in this research in this research there were consist of four steps: pre-assessment, cycle 1 , cycle 2 and post assessment.

\section{Pre Assessment}

The pre- Assessment was given on February, $4^{\text {th }} 2016$. The test consisted of 20 questions. The text was multiple choices in narrative text form. The test was given to 27 students at eighth grade of MTSN 1 Kota Bengkulu. The function of pre assessment was to know their background knowledge. The result of pre assessment was:

Table 1: The Result of Students' Pre Assessment Test

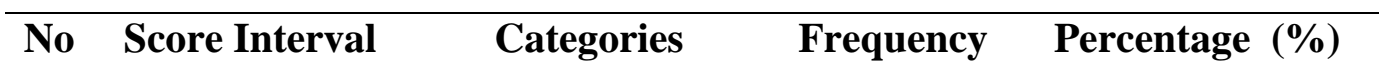

\begin{tabular}{ccccc}
\hline 1 & $86-100$ & Very Good & - & - \\
\hline 2 & $71-85$ & Good & 2 & $7,40 \%$ \\
\hline 3 & $56-70$ & Fair & 11 & $40,74 \%$ \\
\hline 4 & $\leq 55$ & Poor & 14 & $51,85 \%$ \\
\hline
\end{tabular}

Based on the table above, it showed that there was not students' get very good category. There were only 2 or $7,40 \%$ students got good categories, and there were 11 or $40,74 \%$ students' got fair categories, and also there were some students' got poor categories that there were 14 or $51,85 \%$ students. The students' score in pre assessment were average 55,18. After researcher knew students' ability in reading comprehension has poor categories that the researcher applied REAP technique to improving students' reading comprehension. Based on the table above, the researcher got the result of students' score distribution as follows: 
Chart1: The Result of Pre-Assessment

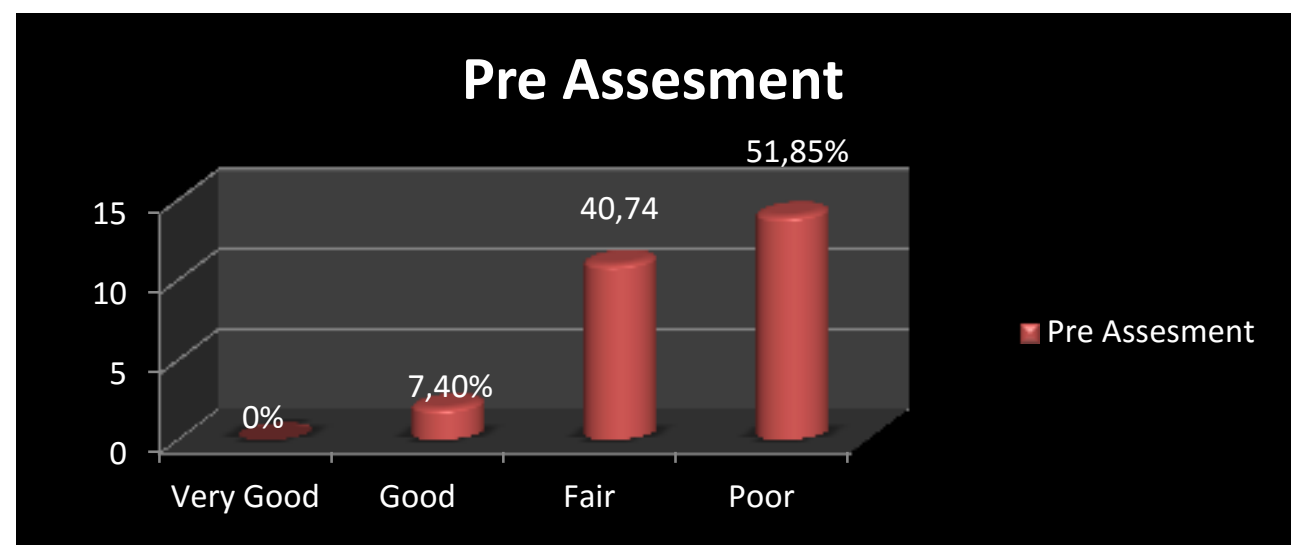

\section{Description of Cycle 1}

After seeing the result of pre assessment, the researcher prepared REAP technique in narrative text to applying in developed students reading comprehension at cycle 1 . It was conducted on Thursday, April, $16^{\text {th }} 2016$, Friday, April, $17^{\text {th }}$ 2016, Thursday, April, $23^{\text {th }} 2016$, Friday, April, $24^{\text {th }}$ 2016.

The researcher tried to choose an easier material to the students in apply of REAP technique. In this cycle there were four phases:

\section{a. Planning}

In this stage, the researcher prepared students REAP technique that taught, like: lesson plan for every meeting, narrative text, teacher and students observation checklist and field notes, worksheet, interview, and question for reading test to know increasing of students reading comprehension that it choose multiple choice of narrative text were consist of 20 items.

\section{b. Action}

In this phase, the researcher applied REAP technique which taken to solve the problem, the first meeting on Thursday, April, 16 ${ }^{\text {th }} 2016$ at class VIII.1 of MTSN 1 Kota Bengkulu. The researcher gave narrative text of
Prambanan Temple. Before explained about this text, the researcher explained about definition, language feature and generic structure of narrative text. After that the researcher explained about how to applying of REAP technique, Almost of students still confused about the technique, because It was new technique for students.

The second meeting was done on Friday, $17^{\text {th }}$ April 2016. The researcher gave apperception and motivation before gave students narrative text. The researcher asked students' knowledge about narrative text and REAP Technique which almost students did not understand but there were some students understand so that it can help the researcher to explain again that technique. The researcher asked some students to make some groups like the first meeting and then the researcher taught and gave a lot pictures. It for each meeting with another pictures' of narrative text so that students were being more interested.

The third meeting was Thursday, April, 23 $3^{\text {th }}$ 2016. The researcher gave material about narrative text like at each meeting before, but in this meeting the 
researcher explained that technique more easy such as following:

- Reading

Students made some group and each group consisted of three or four people. In this steps researcher asked the students to read a text used their own word.

- Encoding

The students tried to encode by putting the gist of what they read in their own words.

- Annotating

In this step, the students were asked to annotate the text by writing down the main ideas (notes, important words, and quotes) and writer's message.

\section{- Pondering}

In this step, the students pondering what they read and than by thinking and talking with others in order to make a personal connection, develop the questions and connected their reading with others reader.

The last meeting in cycle 1 was Friday, April, 24 ${ }^{\text {th }}$ 2016. In this meeting the researcher gave reading test about narrative text that it consist of 20 items multiple choice to measure their improved and to prepare applying in next cycle.

\section{c. Observation}

In this phase, the researcher asked the collaborator to notice all activities that has done by researcher in classroom for instance the researcher' performance, students' respond in class activity and class situations. The collaborator used observation checklist to collected data, the observation checklists were consisted into two kinds, They were students' observation checklist and teacher's observation checklist (see Appendix 6 and 7). Moreover, by the observation, the researcher saw that there were some improvement that are showed by the students, such as: they were enthusiast, some of students gave the question to the researcher if they got confused about material and they felt more interesting with the technique were applied, but the researcher still found that students were not focus.

And then, the students gave positive respond when the researcher explained about REAP technique, during the explanation the students asked researcher to explain it more detail and at end of each meeting, students discussed with the researcher about some problems that they faced in learning process.

Table 2 The result of Students' Reading Comprehension Test Cycle 1

\begin{tabular}{lcccc}
\hline No & Score Interval & Categories & Frequency & Percentage (\%) \\
\hline 1 & $86-100$ & Very Good & - & - \\
\hline 2 & $71-85$ & Good & 12 & $44,4 \%$ \\
\hline 3 & $56-70$ & Fair & 13 & $48,14 \%$ \\
4 & $\leq 55$ & Poor & 2 & $7,40 \%$ \\
\hline
\end{tabular}

From the table above It could seen above that the result of the students' reading comprehension test consisted of there was not students get very good category, 12 or $44,4 \%$ students' who got good categories, 13 or $48,14 \%$ students who got fair categories and 2 or $7,40 \%$ students' who got Poor categories. The mean score was 70,5. Based on the calculated above, It could be showed between the result of pre-assessment and cycle 1 , there were improved of result of their reading comprehension in cycle 1 showed in chart 3 : 


\section{Chart 2: The Result of Reading Comprehension Test Cycle 1}

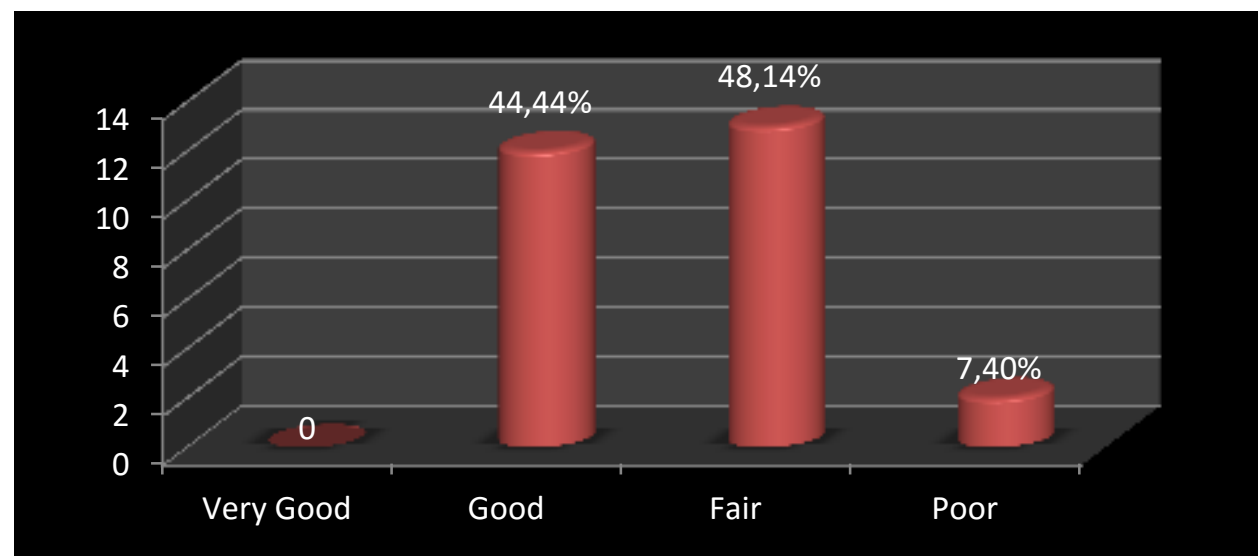

After collected and analyzed the result of reading comprehension test in cycle 1 researcher and collaborator concluded that the result of cycle 1 was better that the result in pre assessment. It could be showed that half of all students who got good categories with percentage $44,44 \%$,

Chart 3: Result of Pre Assessment and Cycle 1.

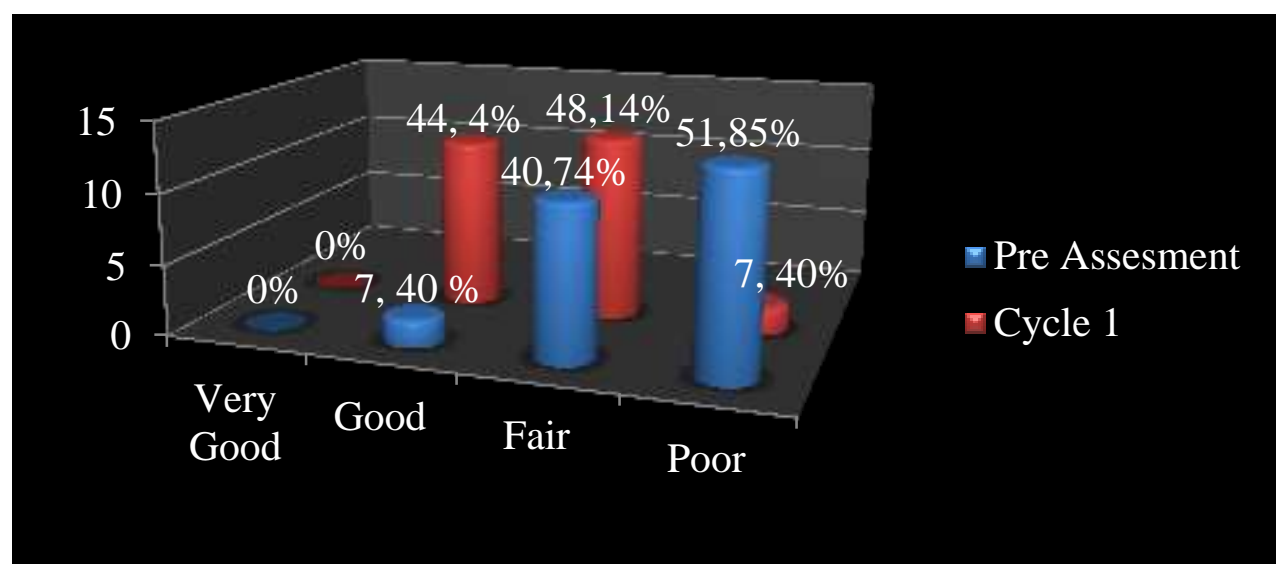

From the chart above, it showed there was raising between pre assesment and cycle 1 , very good was constant $0 \%$, good in Pre Assessment got 7, $40 \%$, in Cycle 1students who got $44,4 \%$. Meanwhile, in fair Pre Assessment got $44,74 \%$, in cycle 1 got $48,14 \%$. And then, in Pre Assessment students' who got Poor categories $51,85 \%$, in cycle 1 got $7,40 \%$.

\section{d. Reflection}

After teaching and learning process, the researcher and collaborator discuss about action in cycle 1 . The result of applying REAP technique was analyzed to measure the success level on cycle I. the result got as the consideration for next cycle. Whether, The next cycle was needed or not. The students' scores on cycle I was better than of Pre Assessment. Through result of 
reading comprehension test in cycle 1 it showed there were some students it around 12 students pass indicator of success which is 75 .

\section{Description of Cycle 2}

After the researcher apply REAP technique in cycle 1 , the researcher prepare to apply in cycle 2 . It was done from on Thursday, April $30^{\text {th }}$, 2016, Thursday, May $7^{\text {th }}$ 2016, and Friday May $8^{\text {th }} 2016$, Friday, May $15^{\text {th }} 2016$

\section{a. Planning}

In this phase, the researcher identified the problem which seen in teaching and learning process and found an alternative way to solve the problem. Based on the students' score on cycle 1 that it showed some students' comprehension on reading was still low. It showed that 14 students got under of indicator success. It was assumed the researcher needed to be more creative in applied REAP technique to improving the students' motivation and comprehension in learning reading. The researcher also designed the teaching material more interested and appropriate with the REAP technique. In this steps the researcher focused on giving clear explanation of REAP technique and gave more interesting examples of narrative text. It could make the students more interested to learn. The similar with cycle 1 the researcher prepare all of needed, such as: Lesson plan, Syllabus, teacher observation checklist, students' observation checklist, interview and all material to support in applying REAP technique.

\section{b. Action}

After preparing English teaching material and the instrument used in action 2, the researcher did the action with the procedure below:

\section{1) Pre Reading Activities}

a. The teacher greeted and checked students' attendant list.

b. The researcher gave brainstorming about English material which it was taught before come directly to the material. Then, REAP which had been revised was applied with the steps as follows:

\section{2) Reading}

Students made some group and each group consisted of three or four people. In this steps researcher asked the students to read a text used their own word.

\section{3) Encoding}

The students tried to encode by putting the gist of what they read in their own words.

\section{4) Annotating}

In this step, the students were asked to annotate the text by writing down the main ideas (notes, important words, and quotes) and writer's message.

\section{5) Pondering}

In this step, the students pondering what they read and than by thinking and talking with others in order to make a personal connection, develop the questions and connected their reading with others reader. After the researcher explained again the steps above and then gave a chart for each group to made students clear about this technique, so the students can followed that steps and to avoid confused in understand purpose of the researcher. 


\begin{tabular}{ll}
\hline $\begin{array}{l}\text { R : Reading } \\
\bullet \quad \text { Title }\end{array}$ & $\begin{array}{r}\text { E: Encoding } \\
\text { - Main idea } \\
\text { - Difficult words' }\end{array}$ \\
\hline $\begin{array}{l}\text { A: Annotating } \\
\text { A statement of summaries } \\
\text { important point }\end{array}$ & $\begin{array}{l}\text { P: Pondering } \\
\text { Write what the author hoped the } \\
\text { reader to learn from the text (Moral } \\
\text { Value). }\end{array}$ \\
\hline
\end{tabular}

After applying the steps of REAP technique, as in cycle 1 which in cycle 2 also, that done test for reading comprehension, to know the result of students' comprehension of reading narrative text.

\section{c. Observation}

In this step, researcher was helped by the collaborator to observe the teaching and learning process. All of data from observation stage in cycle 2 was also collected by using observation checklist of students and teacher's observation checklist, Furthermore, the result of observation checklist of student's in cycle 2 was good categories; the students' attitude during the learning process and teacher's performance were improved.

Based on the result observation there were some improvement of students' in teaching and learning process in the classroom. The first, based on the observation checklist of students' activity, the students' preparation of REAP was checked "yes" category. Most of the students showed that well preparation both in facing the learning process and in preparing all the things needed in learning activity.

Second, students' interests towards REAP technique and toward the material given were good enough. The students' attention toward the explanation of narrative text was checked "yes". They were more interested and gave positive feedback to the explanation about REAP technique. Some students were brave to share their knowledge or asked something about the material and the technique used.

Third, the observation about the students' attitude toward REAP technique. The first step was about sitting in their group. In this step, the students' attitude was good. They directly sat with their groups when the researcher asked them to sit in their group. The result of cycle 2 showed that there was significant improvement from cycle 1 to cycle 2 . Besides, reading test was given in the end of cycle 2 , the student's score presented by used the following table:

Table 3: The Distributor of Students' Score on Cycle II

\begin{tabular}{ccccc}
\hline No & Score Interval & Categories & Frequency & Percentages (\%) \\
\hline 1 & $86-100$ & Very Good & 0 & $0 \%$ \\
\hline 2 & $71-85$ & Good & 24 & $88,88 \%$ \\
\hline 3 & $56-70$ & Fair & 3 & $11,11 \%$ \\
\hline 4 & $\leq 55$ & Poor & 0 & $0 \%$ \\
\hline
\end{tabular}




\section{Chart 4: The Result of Reading Comprehension Test Cycle 2}

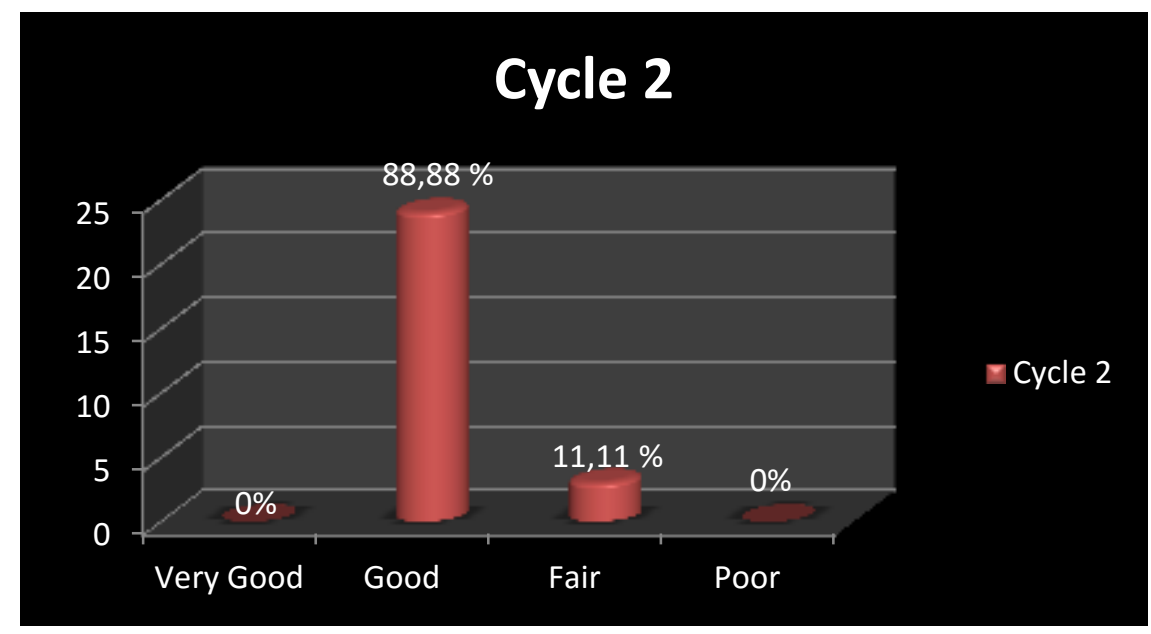

From the chart above, it could be showed that there was no students get very good in cycle 1 that it same with cycle 2 . However, in cycle 1 there were 12 students got good categories, and in cycle 2 there were 24 students' or $88,88 \%$ got good categories. Furthermore, 13 students got fair categories in cycle 1 and 3 students' or $11,11 \%$ who got fair categories in cycle 2 . There were 2 students got poor categories in cycle 1 and in cycle 2 there was no students' poor categories. And the mean score in cycle 2 was 78,7.

\section{d. Reflection}

Based on result of reading comprehension test in cycle 1 and cycle 2, the researcher concluded that there were some improvement, and also based on the result of observation checklist and field notes. Both the good attitudes and create spirit students' during the teaching learning process.

\section{Description of post assessment}

The post assessment was given on Thursday $21^{\text {th }}$ May 2016. The test consisted of 20 questions, the text was multiple choices that it same with pre assessment. The purpose of post assessment was to know students' improve from pre assessment, cycle 1 , cycle 2 and post assessment. The result of post assessment was:

Table 4: The Distributor of Students' Score on Post Assessment

\begin{tabular}{lllll}
\hline No & Score Interval & Categories & Frequency & Percentages (\%) \\
\hline 1 & $86-100$ & Very Good & 7 & $25,92 \%$ \\
\hline 2 & $71-85$ & Good & 18 & $66,66 \%$ \\
\hline 3 & $56-70$ & Fair & 2 & $7,40 \%$ \\
\hline 4 & $\leq 55$ & Poor & - & - \\
\hline
\end{tabular}

Based on the table above, the result of the students' reading comprehension test consisted of 7 student's or $25,92 \%$ who got very good categories, 18 student's or $66,66 \%$ who got good, 2 or $7,40 \%$ students' was got fair categories, and then, there was no students has poor 
categories in this cycle from the average of students' sore was 82,2 . It means that there was improve the result of pre assessment, cycle 1 and cycle 2 .

Chart 5: the Result of Post Assessment

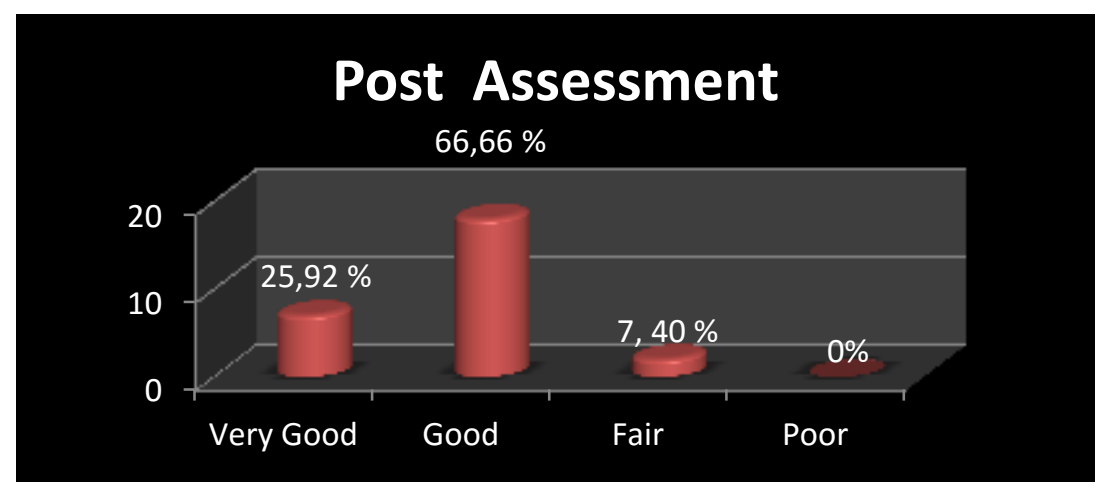

Result

Based on the data analyzed, that it in pre assessment, cycle 1 , cycle 2 and post assessment were showed improving of reading test from pre assessment was
55,1 , cycle 1 was 70,5 , cycle 2 was 78,7 and post assessment was 82,2 . So that, it concluded there was 27,1 increasing from pre assessment to post assessment.

\section{Chart 6: The charts were compared of Result among Pre Assessment, Cycle 1, Cycle 2 and Post Assessment.}

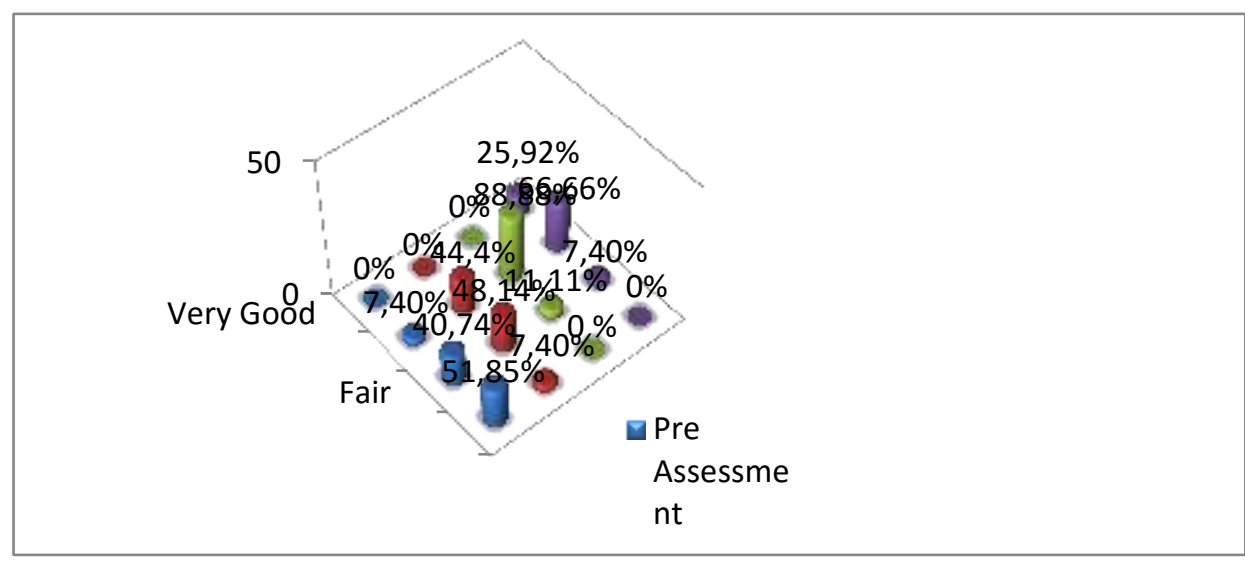

Finally, from discussion above, the researcher concluded that REAP technique was effective to improve the students' reading comprehension and also make the students interested, motivated, and enjoyed in teaching learning process.
The factors that improved the students' reading comprehension at Eighth grade in MTSN1 Kota Bengkulu.

There was some factors improved of students' reading comprehension used reading, encoding, annotating and pondering technique. It could be seen 
through result of reading test in every cycle that it showed based teacher observation checklist and field note, and students observation checklist and field note, :

The first factor, the material was chosen made students more interest. Based on students observation checklist and field notes, it showed that enthusiast of students from the first meeting in applying of REAP technique, based on result of interview done by researcher to some students that it can concluded:

1. The researcher: What do you think about Reading, encoding, annotating and pondering (reap)? Do you interest or not?

2. The students: I hoped you could use Indonesia language miss, so that, we can understand.

3. The researcher: Oke, now I will use Indonesia language, what do you think about Reading, encoding, annotating and pondering (reap)? Do you interest or not?

4. The students: More than interesting miss, the first the story of narrative text can be easier to understand and more interested miss caused the material was chosen used pictures).

The next factor was applying of REAP technique, based on observation checklist and field notes, there applied were positive respond toward REAP technique, Students' felt most easier in reading comprehension test because the researcher give them a chart about REAP technique. In this stage the first researcher explained that steps, although in the first meeting students felt confused. But, after the researcher explained again in the next meeting, students could enjoy learn narrative text used chart and pictures, result of interview has done by researcher toward some students were:

1. The researcher: What do you think about differences between reading before and after using REAP technique?

2. The students: The first applied this technique that made us confused Miss, because there were charts. But, after applied Miss explained again we were understand and could fill that chart consist of the function. Such as: the first chart was for title, the second chart for main idea, etc.

Furthermore, based on interview students 3, after applying cycle 2 was:

1. The researcher: What are you suggestion for REAP in reading narrative text later?

2. The students: We want this technique often to use in the future. Especially, for reading and writing learning process. Because, we were more enthusiastic and enjoyed. Because through by this strategies, we were not bored, because used chart and picture. Moreover, if we found difficult words in text we could write in the second chart, after that, It do discussion and translated together.

And the last, from the presentation above the researcher can concluded that REAP technique was effective to used in junior high to improve reading comprehension, and through REAP technique, it created the process of teaching and learning reading more interested so students could enjoyed and got motivation.

The researcher did the research at eighth grade of MTSN 1 Kota Bengkulu. The result of this research showed after giving treatment for one month. It could be taken some conclusion that most of 
students were enthusiast and interested in the material given through REAP technique. Most of them got better percentage comprehension in significant level from two actions at end cycle.

Before the researcher did treatment, the researcher did pre assessment. The result showed that there were no students get very good. Therefore, they needed to improve their abilities in reading comprehension. The researcher also indicated that student's REAP technique in reading comprehension could improved the students reading comprehension.

\section{CONCLUSION AND SUGGETION}

Reading is a process of readers to get information by studying about word and then understood the meaning of those words. Reading comprehension is a process to get information by combining readers' background knowledge with the new information from the text in order to comprehend the text. So reading is not just now about words in the text but also understand about the meaning of text. So in teaching reading comprehension, teacher should use the good technique in order to make students easy comprehending the text.

In this papers researcher used Reading, Encoding, Annotating and Pondering Technique. So that, Based on the result of this research, REAP technique can be used as the alternative in teaching reading, especially in teaching reading narrative text. This technique made students more easier in understand a text it showed in the result of post assessment student's toward score was 82,2 in reading test, developed students' ability in writing the annotation about the main ideas of a text.
It improve students' reading comprehension and increase academic achievements, it was proved by mean score improvement of reading test from pre assessment was 55,1 , cycle 1 was 70,5 and cycle 2 was 78,7, and the student's score in post assessment was 82,2 . So that, there was 27,1 increasing from pre assessment to post assessment. The students at MTSN 1 Kota Bengkulu more active and have good attitude. Furthermore, this technique would be more applicable to increase students in understanding a material. Moreover, Students would be more motivated so that, It can be concluded REAP technique was success and effective to improve students' reading comprehension especially at MTSN 1 Kota Bengkulu in academy years 2014/2015.

The suggestion as follow:

1. REAP technique is actually one of the alternatives way to teach reading in the classroom, because it can built the enthusiast, interest and made learning English running well. So, the teacher should create good situation, good emotion, and good condition in classroom.

2. It is better for teachers who teach English, especially teaching reading to pay attention to the problems that are faced by the students learning. The teacher must solve the problem by using the appropriate and effective strategy in teaching and learning process. Teaching reading through REAP can be alternative choice to solve the problems of students in learning.

3. Variety in teaching reading, such as REAP is needed to support the purpose of teaching reading. The 
further research in needed, in order to improve the research finding such as: how to manage the reading for pleasure and interest for the teaching reading purpose, and how to prepare the material for classroom activities.

4. For another researcher, it is very important to find out and investigated another technique to be compared with this technique. So, the researcher can bring the best technique to be applied in learning and teaching reading in the classroom

5. The last, the researcher recommended for English teacher especially in MTSN 1 Kota Bengkulu to find as many as good reading comprehension strategies or technique, it hopes can create better reading comprehension ability for the students. So that, the students can be more achievement.

\section{REFERENCES}

Fauziyah, Yahya. 2014. The Effectiveness of Using Reading, Encoding, Annotating and Pondering (REAP) Technique Towards Students' Reading Skill of Descriptive Text (A QuasiExperimental Study at the Seventh Grade of MTs Salafiyah) Unpublished Thesis, UIN Syarif Hidayatullah, Jakarta.

Marantika, Putri. "The R.E.A.P Technique For Teaching Reading a Narrative Text to Junior High School Students", Journal of English Language teaching, , Vol. 1 No. 2, September 2013, Series A P. 72 .

Manzo, Anthony, Manzo Ula, and Albee, Julie Jackson. 2002. REAP: Improving reading, writing, and thinking in the wired classroom. Journal of Adolescent \& Adult Literacy; Sep2002, Vol. 46 Issue 1, p42. Retrieved on 17 February 2015 , from www.jstor.org/stable/40017504.

Martono, Nanang. 2012. Metode Penelitian Kuantitatif. Jakarta: Rajawali Press.
Napitupulu, Helentina, Merlina. 2012.The Effect of Teaching Strategies and Cognitive Style on Reading Comprehension. English Applied Lingustics, Post Graduate. Unpublished Thesis.

Nunan David. 1995. Language Teaching Methodology. British :Redwood Books.

Nunan David. 1989. Understanding Language Classroom. New York: Great Britain.

Nuttall Christine. 1996. Teaching Reading Skills in a foreign language. Britain: The Bath Press.

Sam's, Hartiny, Rosma. 2010. Model PenelitianTindakan Kelas. Yogyakarta: Teras.

Susanti Rini. 2012. Teaching Reading by Combining Reap (Reading, Encoding, Annotating, Pondering) Technique and Exit Slips Technique at Senior High School. Unpublished Thesis, STKIP PGRI Sumatera Barat.

Tibebu Tiruneh, Dawit" The Effect of Explicit Reading Strategy Instruction on Reading 
164 Ta'dib, Volume 19, No. 2 (Desember 2016)

Comprehension of Upper Primary

Grade Students" (International journal: 2014 V 6, N 3).

Ur Penny . 1996. A Course in Language

Teaching. Australia: Cambridge University.
Ur Penny. 1997. A Course in Language Teaching. Australia: Cambridge University.

Weir Cyril. 1993. Understanding and Developing Language Test. Europe: Prentice Hall Europe. 